\title{
SOME PHYSICAL, MECHANICAL AND AERODYNAMIC PROPERTIES OF QUINOA SEEDS
}

(Chenopodium quinoa Willd)

\author{
Badr,M. M.* and EISSA, A. S.**
}

\section{ABSTRACT}

The aim of the present study is to study some physical, mechanical and aerodynamic properties of quinoa seeds (Chenopodium quinoa Willd.), to help in designing and developing of specific machine and their operations such as harvesting, cleaning and milling processes. The properties were determined at moisture content of quinoa seed $11.60 \%$ d.b. Three principal dimensions (length, width and thickness) of quinoa seeds were measured using image-processing technique. The highest value of seed length, width and thickness were 2.91, 2.68 and $1.10 \mathrm{~mm}$ respectively, while the lowest value of seed length, width and thickness were $1.38,1.12$ and $0.49 \mathrm{~mm}$ respectively. The highest value in dynamic angle of repose $30.0^{\circ}$ for plastic while the lowest value in dynamic angle of repose $26.3^{\circ}$ for galvanized sheet. The lowest values of static coefficient of friction was 0.46 with plywood while the highest value was 0.65 with glass. The seeds gave values of $0.79 \mathrm{~m} / \mathrm{s}$ and 88.25 for average terminal velocity and average Reynolds number respectively, so, the flow was laminar.

\section{1-INTRODUCTION}

uinoa originates from South America where it grows at high altitudes. Bolivia and Peru are the biggest exporters with $88 \%$ of the worldwide production, followed by the United States of America with 6\%. The seed is resistant to drought and frost and frequently is cultivated on poor soils (Brenes et al., 2001). Quinoa is a complete food with high-nutritional value due mainly to its high content of good quality protein. Besides protein content, it also contains minerals and vitamins like vitamin $B$, vitamin $C$ and vitamin $E$.

\footnotetext{
*Assoc. Prof. of Ag. Products Process Eng. Dept., Fac. of Ag. Eng., Al Azhar Univ., Cairo, Egypt.

**Lecturer of Ag. Products Process Eng. Dept., Fac. of Ag. Eng., Al Azhar Univ., Cairo, Egypt.
} 
In 1996, quinoa was catalogued by FAO as one of the most promising crops for the humanity, not only for its great properties and its multiple uses, and it is also considered an option to solve human nutrition problems (FAO, 2011). Quinoa flour is low in gluten due the low content of polyamines and glutamines. It is usually used to enhance baking flours in the preparation of biscuits, noodles and pastries and for the preparation of baked foods to maintain the moisture and give an agreeable flavoring comparison to common cereals, quinoa is higher in protein, lysine, fat and fiber and protein quality was shown to be high. (Vilche et al.2003)Protein content in the dry matter of quinoa seeds varies between $13.8 \%$ and $16.5 \%$; however, it is reported as $15 \%$ on average. The total protein content of quinoa is higher than that of rice, barley, corn, rye, and sorghum, and is close to wheat(USDA, 2015). There are some gluten-free products without good baking properties for celiac groups, and quinoa provides an opportunity to develop gluten-free cereal-based products showed that quinoa can be used to make novel, healthy, extruded, snacktype food products. (Gallagher et al., 2004)The determination of the physical, mechanical and aerodynamic properties of quinoa seeds like those of other seeds are useful for improving the technology associated with the different operations and equipment related to the postharvest process such as cleaning, classification, transport, aeration, drying and storage.(Kachru et al., 1994). The objective of this study was to investigate physical, mechanical and aerodynamic properties of the quinoa seeds that affect design and development of the postharvest process such as transporting, grading, grinding, drying and storage.

\section{2-MATERIALS AND METHODS}

\subsection{Sample preparation}

The quinoa (Chenopodium quinoa Willd.) seeds used in the present study were obtained from a Food Science and Technology Dept. Fac. of Agric., Al-Azhar Univ. Cairo, Egypt. The seeds were manually cleaned to remove foreign matter, broken and immature seeds. Fig.(1) a and b show the photograph of Quinoa lands in open field and Quinoa seeds. Seeds were packaged in polyethylene bags and stored under deep freezing. All 
the experiments were carried out in the Fac. of Agric. Eng., Al-Azhar Univ., Cairo, Egypt.

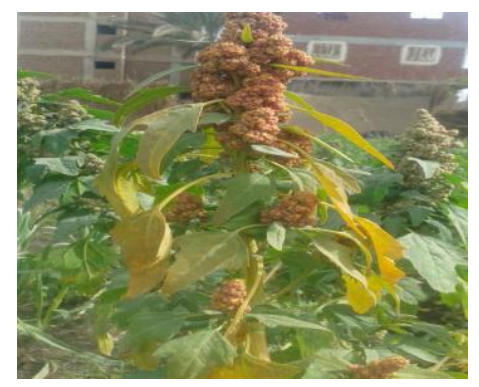

Fig. (1a): photograph of Quinoa plants in open field

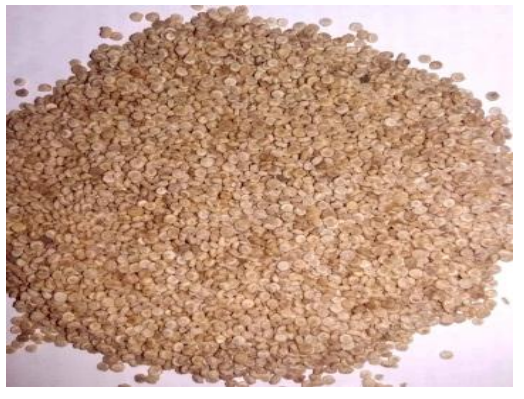

Fig. (1b): Quinoa seeds and their parts.

\subsection{Physical properties of Quinoa seeds}

\subsubsection{Dimensional properties}

\section{The principal dimensions}

Three principal dimensions namely length $\boldsymbol{L}$, width $\boldsymbol{W}$ and thickness $\boldsymbol{T}$ in $(\mathrm{mm})$ as in Fig (2).were measured using image processing technique of 100 seeds selected randomly, and were scanned using a scanner (HP LaserJet Professional M1132 MFP) to capture the image of seeds at natural flat position, then; the pictures of seeds were exported to AutoCAD 2012 program to calculate length $\boldsymbol{L}$, width $\boldsymbol{W}$ and thickness $\boldsymbol{T}$.
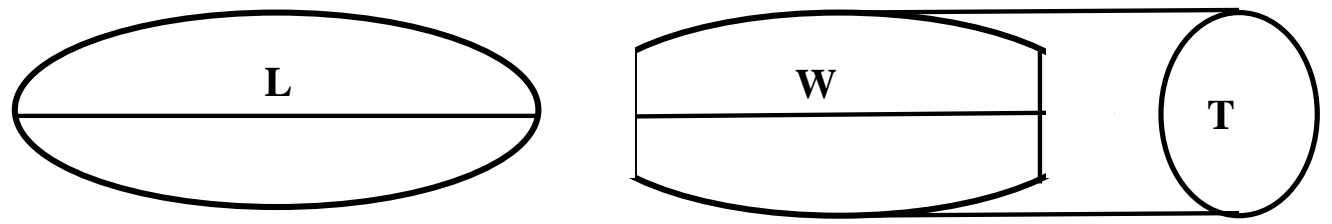

Fig (2): Characteristic dimensions of quinoa seed: length $L$, width $W$ and thickness $\mathbf{T}$

\section{The average diameter and volume}

Some dimensional properties of quinoa seeds were calculated based on the length $\boldsymbol{L}$, width $\boldsymbol{W}$ and thickness $\boldsymbol{T}$. Geometric mean diameter $\boldsymbol{D}_{\boldsymbol{G}}$ in $\mathrm{mm}$, arithmetic mean diameter $\boldsymbol{D}_{\boldsymbol{A}}$ in $\mathrm{mm}$ and volume " $\boldsymbol{V}$ in $\mathrm{mm}^{3}$ of an 
individual seed were calculated using Eqs. (1), (2) and (3). according to, Mohsenin (1986).

$$
\begin{aligned}
& \mathrm{D}_{G}=\sqrt[3]{\mathrm{L} \cdot \mathrm{W} \cdot \mathrm{T}} \\
& D_{A}=\frac{L+W+T}{3} \\
& \mathrm{~V}=\frac{\pi}{6}(\mathrm{~L} \cdot \mathbf{W} \cdot \mathrm{T})
\end{aligned}
$$

\section{Seed surface area $\left(\mathbf{S}_{\mathrm{A}}\right)$}

The surface area is defined as the outside total area of the seed. The surface area of quinoa seeds $S_{\mathrm{A}}$ in $\mathrm{mm}^{2}$ was calculated by analogy with a sphere of the same geometric mean diameter using the following equation according to, Siqueira et al. (2013).

$$
S_{A}=\pi\left(D_{G}\right)^{2}
$$

The surface area of seeds is very important characteristic in determining both volumetric and gravimetric heat transfer coefficient and in analyzing heat and moisture transfer during drying processes, and it is also useful for describing the rehydration process.

\section{- The sphericity of seeds}

The sphericity $\varnothing$ defined as the ratio of the surface area of sphere having the same volume as that of the seed to the surface area of the seed, was determined using the following equation (Mohsenin, 1986):

$$
\emptyset=\frac{\boldsymbol{D}_{G}}{\mathbf{L}} \ldots \ldots \ldots
$$

Where $0<\varnothing \leq 1$

\section{Mass and thousand seeds mass}

A random sample of one thousand seeds was taken by seed counter and weighed by an electric digital balance, Sartorius: 1413-MP8-1, manufactured in Germany with accuracy of $0.001 \mathrm{~g}$. The mass of each treatment was replicated three times.

\section{Bulk density, real density and Porosity}

The bulk density $\boldsymbol{\rho}_{\boldsymbol{b}}, \mathrm{kg} / \mathrm{m}^{3}$ of seeds was determined using a graduated cylinder of $250 \mathrm{ml}$, the volume was determined by put quantity of seeds in the previous graduated cylinder. To achieve uniformity in bulk density, the graduated cylinder was tapped 10 times for the seeds to consolidate 
this process were repeated ten times. The bulk density was calculated for the seeds by dividing the mass of quantity of seeds $\boldsymbol{M}_{\boldsymbol{b}}, \mathrm{kg}$ on its volume $\boldsymbol{V}_{\boldsymbol{b}}, \mathrm{m}^{3}$ as the following equation:

$$
\rho_{b}=\frac{M_{b}}{V_{b}}
$$

The real density $\boldsymbol{\rho}_{\boldsymbol{T}}, \mathrm{kg} / \mathrm{m}^{3}$ is defined as the ratio of mass of individual seed to its actual volume. A digital balance measured mass of the samples of seeds with accuracy of $0.001 \mathrm{~g}$. And volume of the samples of seeds was calculated based on the water displacement method; toluene $\left(\mathrm{C}_{7} \mathrm{H}_{8}\right)$ was used instead of water, because its absorption by seeds is less than water; also its surface tension is low, so that it fills even shallow dips in a seed and its dissolution power is low Mansouri et al., (2017). The real density was calculated by finding the ratio of mass $\boldsymbol{M}_{\boldsymbol{t}}, \mathrm{kg}$ to actual volume $V_{t}, \mathrm{~m}^{3}$ of displaced water as the following equation according to, Mohsenin (1986).

$$
\rho_{T}=\frac{M_{t}}{V_{t}}
$$

The porosity $\varepsilon \%$ of seeds was calculated from values of bulk and real densities using the following equation according to, Mohsenin (1986).

$$
\varepsilon=\left(1-\frac{\rho_{b}}{\rho_{T}}\right) \times 100
$$

\subsubsection{Moisture content}

The moisture content of quinoa seeds were determined by drying method in a hot air oven at $105^{\circ} \mathrm{C}$ for 24 hours. This test was repeated six times.The moisture content of the samples was determined by using the standard method of ASAE (ASAE Standard, 1999).

Moisture content $\boldsymbol{M}$ (d.b), (\%):

$$
M=\frac{W_{m}}{W_{d}} \times 100
$$

Where:

$W_{m}$ : Mass of moisture in sample, $(\mathrm{g})$; and

$W_{d}$ : Mass of bone-dry material, $(\mathrm{g})$.

\subsection{Mechanical properties of quinoa seeds}

\section{Repose angle}

The angle of repose is the angle between a horizontal surface and inclined side of the formed cone due to free fall of materials. Static angle of repose 
was measured using pouring method, the angle of repose of seeds sample was determined using PVC cylinder of $100 \mathrm{~mm}$ height and $40 \mathrm{~mm}$ diameter. The different material surface namely: galvanized sheet, glass, plywood and plastic were used for measuring it. The diameter and height of the seeds pile were measured and recorded. This experiment was repeated ten times and the dynamic angle of repose for each replication was calculated using the following equation:

$$
\alpha=\tan ^{-1} \frac{2 H}{D}
$$

Where

$\boldsymbol{\alpha}=$ is the angle of repose, (degree)

$\boldsymbol{H}=$ is the height of the pile, $(\mathrm{mm})$

$\boldsymbol{D}=$ is the diameter of the pile, $(\mathrm{mm})$.

\section{Coefficient of static friction}

The friction angle was measured by an instrument fabricated in the workshop of Agricultural Engineering Faculty Al-Azhar University, Nasr city, Cairo. An open-ended transparent plastic cylinder having $50 \mathrm{~mm}$ internal diameter and $40 \mathrm{~mm}$ height was placed on adjustable tilt: $\sim$ plate $(300 \mathrm{~mm} \times 175 \mathrm{~mm})$. The hollow cylinder was filled with the seeds, ${ }^{3} \mathrm{n}$; the cylinder 2 is raised about $5 \mathrm{~mm}$ so as not to touch the surface. Manually, inclination of the plate was increased gradually until the filled cylinder just started to slide down. The instrument was used to measure the angle of static friction for the different material surfaces, namely: galvanized sheet, glass, plywood and plastic. This experiment was repeated ten times and the coefficient of static friction for each replicate was calculated using the following equation:

Static Coefficient of friction $=\tan \theta$

\section{Where:}

$\boldsymbol{\theta}=$ the tilt angle between the surface and the horizontal.

\subsection{Aerodynamic properties of quinoa seeds}

\section{Terminal velocity}

The terminal velocity was measured using a terminal velocity apparatus. This apparatus was constructed according to Awady and El- sayed (1994), as shown in Fig. (3). The apparatus consisted of a rectangular tube constructed from transparent plexi-glass and connected with the outlet of the 
electrical blower. The outlet of blower was covered with a wire mesh to ensure the distribution of air flow in the cross-section of the rectangular tube. A part of sheet iron was put above inlet of the blower to control in the air flow rate manually. The seed was put on the lower screen, terminal velocity can be obtained by measuring the air velocity required to suspend the seed in the vertical air stream. Air velocity was measured at the bottom of the tube by an anemometer (range e of measurement 0 to $30 \mathrm{~m} / \mathrm{s}$ with accuracy of $0.1 \mathrm{~m} / \mathrm{s}$ ). The air velocity changes with change in the crosssection of the tube. The value of the terminal velocity $\boldsymbol{U}_{\boldsymbol{t}}$ was calculated using the following equation:

$$
\boldsymbol{U}_{t}=\frac{\boldsymbol{Q}_{\boldsymbol{a}}}{\boldsymbol{A}} \ldots \ldots \ldots \ldots \ldots \ldots \ldots \ldots \ldots \ldots \ldots \ldots \ldots \ldots
$$

Where:

$\boldsymbol{U}_{t}:$ is the terminal air velocity, $(\mathrm{m} / \mathrm{s})$.

$Q_{a}:$ is the air flow rate, $\left(\mathrm{m}^{3} / \mathrm{s}\right)$.

$\boldsymbol{A}:$ is the cross-section area of the tube, $\left(\mathrm{m}^{2}\right)$.

\section{Reynolds number}

The Reynolds number was calculated using the following equation according to, Mohsenin (1986).

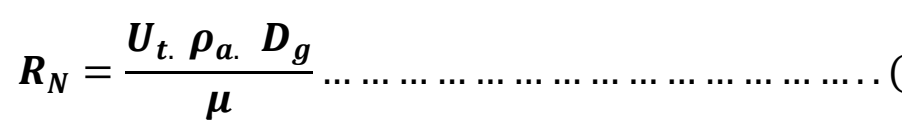

Where:

$\boldsymbol{R}_{N}$ : is the Reynolds number, (dimensionless).

$\boldsymbol{\rho}_{\boldsymbol{a}}$ : is the air density at temperature $293 \mathrm{~K},\left(1.205 \mathrm{~kg} / \mathrm{m}^{3}\right)$.

$\boldsymbol{U}_{\boldsymbol{t}}$ : is the air terminal velocity, $(\mathrm{m} / \mathrm{s})$.

$\boldsymbol{D}_{\boldsymbol{G}}$ : is the geometric mean diameter of seeds, $(\mathrm{m})$.

$\boldsymbol{\mu}$ : is the dynamic viscosity of the air at temperature $293 \mathrm{~K},\left(1.821 \times 10^{-5}\right.$ $\mathrm{kg} / \mathrm{m} . \mathrm{s})$.

$\mathrm{U}_{\mathrm{T}}$ transitional flow at $2100<\mathrm{R}_{\mathrm{N}}<4000$, (flow in pipes).

\subsection{Statistical analysis}

The data obtained were subjected to descriptive statistics such as; range (maximum "Max" and minimum "Min"), mean, standard deviation (SD), coefficient of variation (CV), frequency distribution and coefficient of correlation by using spreadsheet software program (Microsoft Excel). 


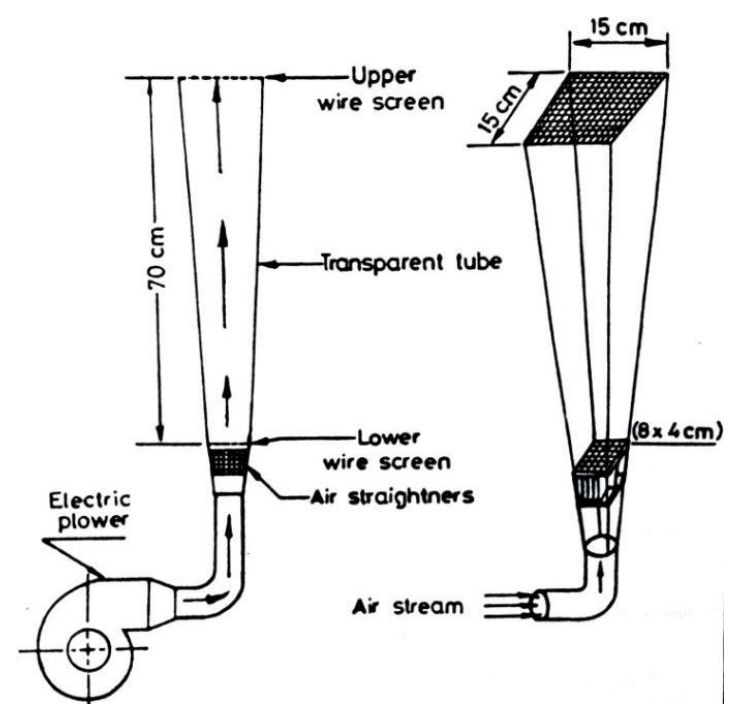

Fig. (3): Terminal air velocity apparatus,

\section{RESULTS AND DISCUSSION}

Physical, mechanical and aerodynamic properties of Quinoa seeds under study were conducted in Faculty of Agricultural Engineering, Al-azhar University.

\subsection{Physical properties}

\section{The principal dimensions}

Averages of one hundred seeds for the three principal dimensions. Standard deviation and coefficient of variation are shown in table (1). The measurements of length $\boldsymbol{L}$, width $\boldsymbol{W}$ and thickness $\boldsymbol{T}$ in (mm). The highest value of seed length, width and thickness were 2.91, 2.68 and $1.10 \mathrm{~mm}$ respectively, while the lowest value of seed length, width and thickness were $1.38,1.12$ and $0.49 \mathrm{~mm}$ respectively.

Table (1): The principal dimensions of Quinoa seeds.

\begin{tabular}{cccccc}
\hline $\begin{array}{c}\text { The principal } \\
\text { dimensions (mm) }\end{array}$ & Max. & Min. & Ave. & S.D & C.v \% \\
\hline Length & 2.91 & 1.38 & 2.22 & 0.30 & 13.54 \\
Width & 2.68 & 1.12 & 1.92 & 0.29 & 15.26 \\
Thickness & 1.10 & 0.49 & 0.80 & 0.15 & 18.10 \\
\hline
\end{tabular}


Fig. (4, 5 and 6) showed that the highest frequencies of seed length, width and thickness were 29,33 and $29 \%$ at $(1.95-2.15 \mathrm{~mm}),(1.90-2.10)$ and $(0.88-0.96 \mathrm{~mm})$ respectively.

The average diameters, volume, surface area and sphericity of Quinoa seeds

Table (2) shows the seeds geometric diameter $\boldsymbol{D}_{\boldsymbol{G}}$ and arithmetic diameter $\boldsymbol{D}_{\boldsymbol{A}}$. Standard deviation and coefficient of variation The highest value of seed geometric diameter and arithmetic diameter were 2.86 and $2.68 \mathrm{~mm}$ respectively, while the lowest value of seed geometric diameter and arithmetic diameter were 0.25 and $1.00 \mathrm{~mm}$ respectively.

Table (2): The geometric and arithmetic diameter of Quinoa seeds.

\begin{tabular}{cccccc}
\hline Diameters (mm) & Max. & Min. & Ave. & S.D & C.V \% \\
\hline Geometric & 2.86 & 0.25 & 1.22 & 0.52 & 42.55 \\
Arithmetic & 2.23 & 1.00 & 1.65 & 0.24 & 14.80 \\
\hline
\end{tabular}

Fig. (7 and 8) showed that the highest frequencies of seed geometric diameter and arithmetic diameter were 29 and $28 \%$ at $(0.89-1.22 \mathrm{~mm})$ and $(1.00-2.26 \mathrm{~mm})$ respectively.

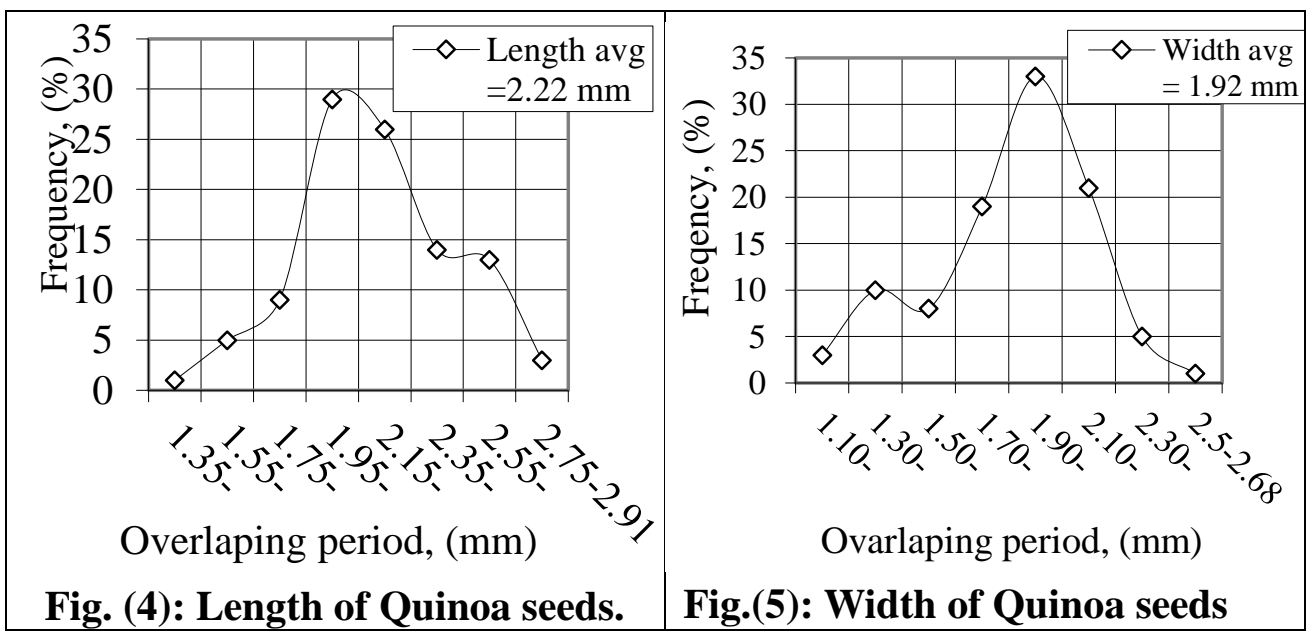



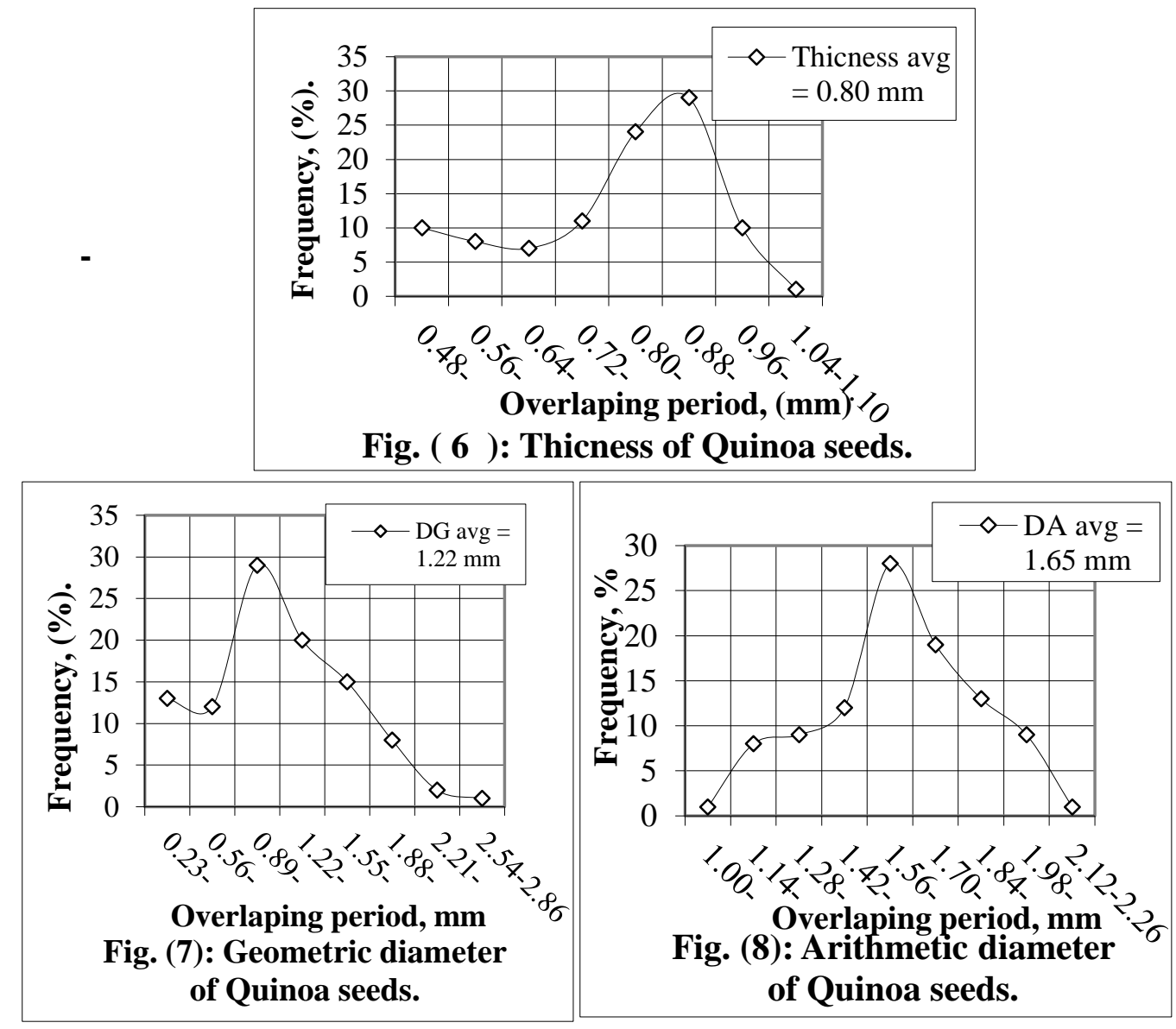

Table (3) shows the volume of seeds. The maximum value of volume is $4.49 \mathrm{~mm}^{3}$, while the minimum value is $0.40 \mathrm{~mm}^{3}$. Fig. (9). Shows that the highest frequency of seed volume was $31 \%$ at $\left(1.40-1.93 \mathrm{~mm}^{3}\right)$.

Table (3): The volume of Quinoa seeds.

\begin{tabular}{cccccc}
\hline Volume $\left(\mathbf{m m}^{3}\right)$ & Max. & Min. & Ave. & S.D & C.V \% \\
\hline Seed volume & 4.49 & 0.40 & 1.91 & 0.81 & 42.55 \\
\hline
\end{tabular}

Table (4) shows the surface area of seeds. The maximum value of surface area is $17.34 \mathrm{~mm}^{3}$, while the minimum value is $0.2 \mathrm{~mm}^{3}$. Fig. (10) Shows 
that the highest frequency of seed surface area was $25 \%$ at $(0.2-2.34$ $\left.\mathrm{mm}^{2}\right)$.

Table (4): The surface area of Quinoa seeds.

\begin{tabular}{cccccc}
\hline Area $\left(\mathbf{m m}^{2}\right)$ & Max. & Min. & Ave. & S.D & C.V \% \\
\hline Seed surface area & 17.34 & 0.20 & 5.41 & 4.07 & 75.36 \\
\hline
\end{tabular}

Table (5) shows the sphericity of seeds. The maximum value of sphericity is 0.98 , while the minimum value is 0.18 . Fig. (11). Shows that the highest frequency of sphericity was $28 \%$ at $(0.48-0.58)$.

Table (5): The sphericity of Quinoa seeds.

\begin{tabular}{lccccc}
\hline \multirow{3}{*}{ Sphericity } & Max. & Min. & Ave. & S.D & C.V \% \\
\cline { 2 - 6 } & 0.98 & 0.18 & 0.53 & 0.16 & 31.03 \\
\hline
\end{tabular}

Mass of 1000 seeds, bulk \& real density, void ratio and moisture content

The measurements of mass of one thousand seeds of Quinoa under study, bulk and real density. Also, void ratio and moisture content were conducted in three replicates.

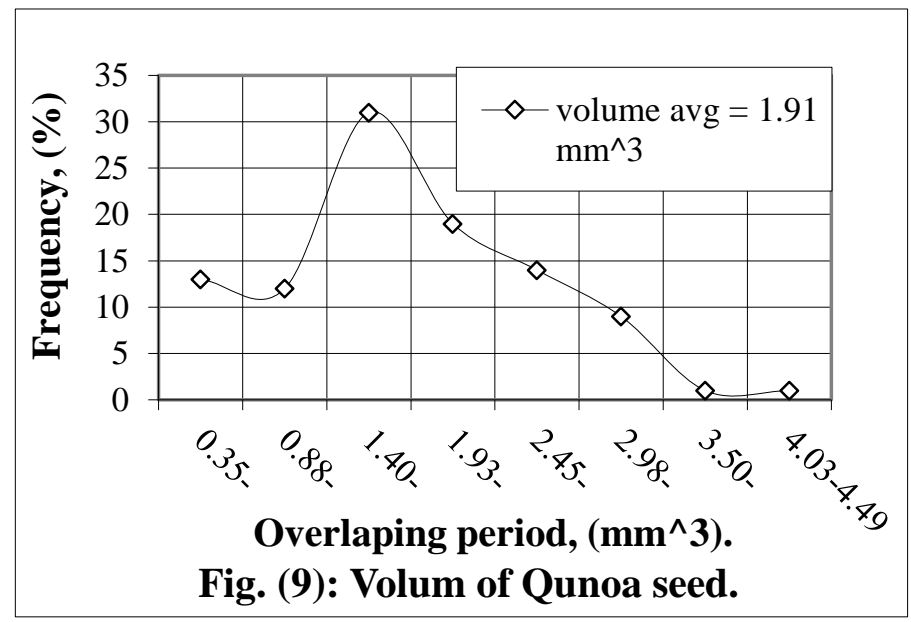



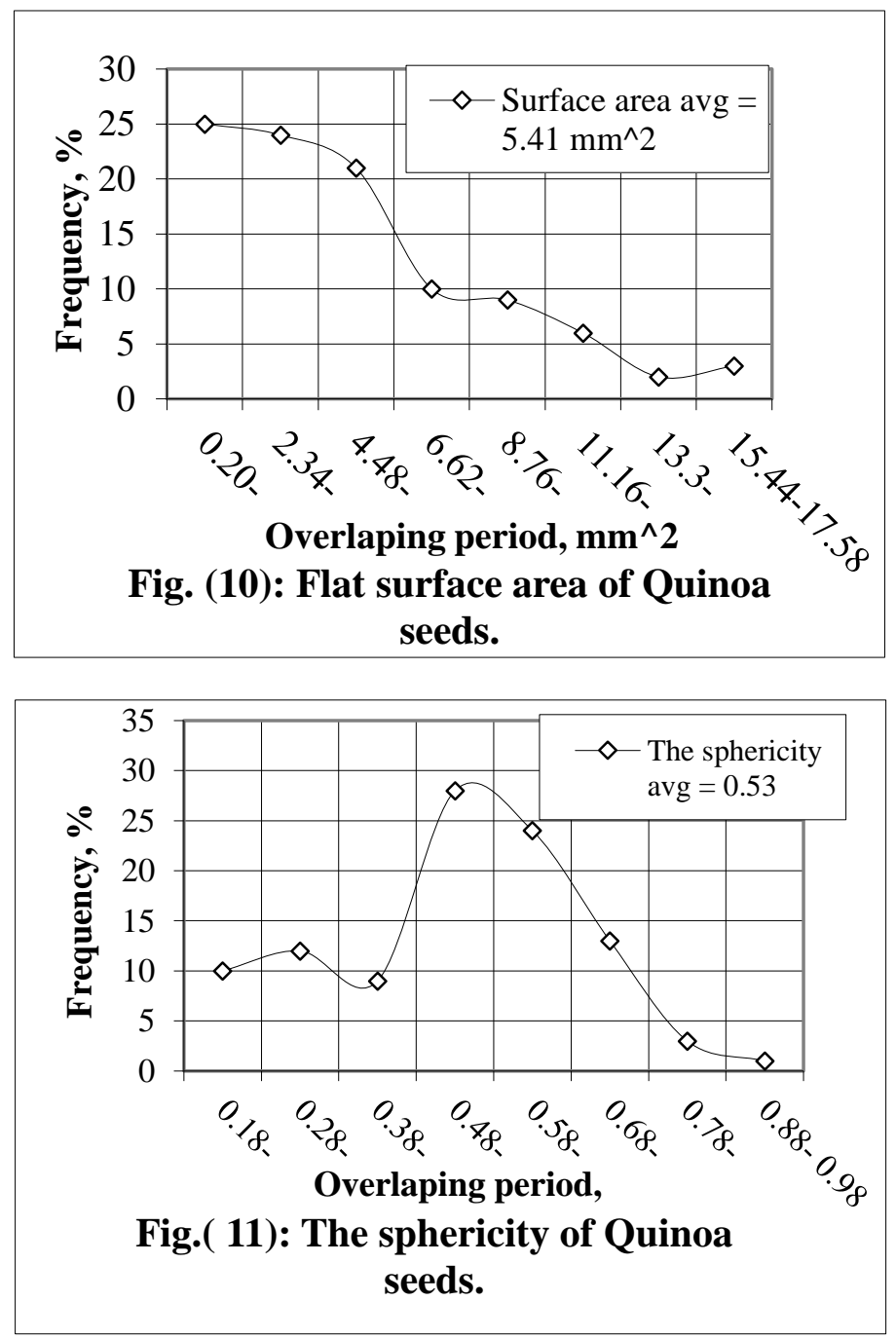

Table (6) shows the other physical characteristics for the mass, real\& bulk density, void ratio and moisture content. It shows that the seeds gave values of $26.82 \mathrm{~g}, 1.27 \mathrm{~g} / \mathrm{cm}^{3}, 0.603 \mathrm{~g} / \mathrm{cm}^{3}, 52.52 \%$ and $11.60 \%$ d.b for mass, real, \& bulk density, void ratio and moisture content respectively. Mass of one thousand seeds is major considerations in designing containers, silos and hoppers. Estimating the mass of seed is necessary to 
assess the required mass of seed for planting a limited area and number of seed in each hole. Bulk and real density are major considerations in designing the sowing, converting, drying, aeration and storage systems, bulk density is also considered for determination of paging capacity, designing seed hopper dimensions in seed planters, cleaning, and grading equipment.

Table (6): The mass, real\& bulk density of one thousand seeds, void ratio and moisture content.

\begin{tabular}{|c|c|c|c|c|c|}
\hline \multirow{3}{*}{ Seeds } & \multirow[t]{2}{*}{$\begin{array}{c}\text { Mass } \\
\text { (g) }\end{array}$} & \multicolumn{2}{|c|}{$\begin{array}{l}\text { Density } \\
\left(\mathrm{g} / \mathrm{cm}^{3}\right)\end{array}$} & \multirow[t]{2}{*}{$\begin{array}{c}\text { Porosity } \\
(\%)\end{array}$} & $\begin{array}{c}\text { Moisture content } \\
\text { (\%) }\end{array}$ \\
\hline & & Real & Bulk & & d.b \\
\hline & 26.82 & 1.27 & 0.603 & 52.52 & 11.60 \\
\hline
\end{tabular}

\subsection{Mechanical properties of quinoa seeds}

\section{Repose angle}

The angle of repose for Quinoa seeds of the investigated variety was $30.0^{\circ}, 26.9^{\circ}, 26.8^{\circ}$ and $26.3^{\circ}$ for plastic, galvanized sheet, glass and plywood respectively. The previous data can be utilized to assess the optimum side's inclination of seed hopper in planting machines, silos and storage containers to allow an easily sliding. The repose angle for Quinoa seeds of the investigated variety on the selected material surfaces including plastic, galvanized sheet, glass and plywood are shown in Fig (12).

\section{Static friction coefficient}

The lowest values of static coefficient of friction were on plywood followed by galvanized sheet, plastic and the highest glass, $(0.46,0.55$, 0.57 and 0.65 ) for the Quinoa seeds respectively. It is recommended to use this material in the structure of seed hopper in planters, silos and storage containers. The static coefficient of friction for Quinoa seeds of the investigated variety on the selected material surfaces including plastic, galvanized sheet, glass and plywood are shown in Fig (13) 

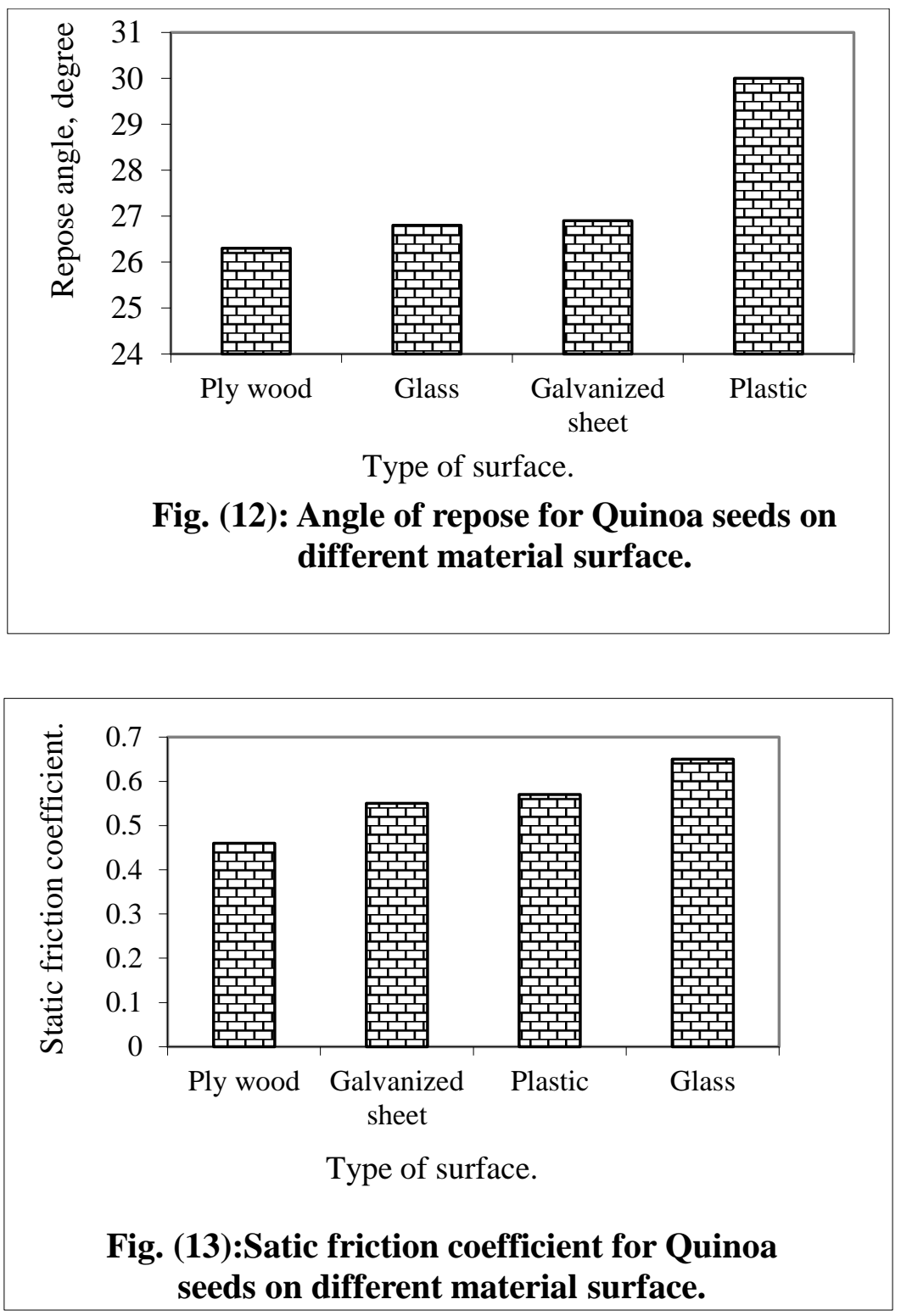

\subsection{Aerodynamic properties of quinoa seeds}

Table (7) shows the aerodynamic properties of quinoa seeds for terminal velocity, and Reynolds number. It shows the highest value of terminal velocity, and Reynolds number were $0.87 \mathrm{~m} / \mathrm{s}$ and 164.6 , while the lowest value 0.72 and 11.9 respectively. The determination of the physical, mechanical and aerodynamic properties of quinoa seeds like those of 
other seeds are useful for improving the technology associated with the different operations and equipment related to the postharvest process such as cleaning, classification, transport, aeration, drying and storage.

Table (7): Aerodynamic properties of quinoa seeds

\begin{tabular}{|c|c|c|c|}
\hline \multirow{2}{*}{ Characteristic } & \multicolumn{2}{|c|}{ Range } & \multirow{2}{*}{ Avg. } \\
\hline & Min & Max & \\
\hline Terminal velocity & 0.72 & 0.87 & 0.79 \\
\hline Reynolds number & 164.60 & 11.90 & 88.25 \\
\hline
\end{tabular}

\section{CONCLUSION}

\section{The results can be summarized as follows:}

1. Some physical properties of averaged values of Quinoa seeds were studied as: length, width, thickness, geometric diameter, arithmetic diameter, volume, flat surface area, sphericity, mass of 1000 seeds, real density, bulk density, porosity, and moisture content dry basis were 2.22 $\mathrm{mm}, 1.29 \mathrm{~mm}, 0.80 \mathrm{~mm}, 1.22 \mathrm{~mm}, 4.40 \mathrm{~mm}, 1.91 \mathrm{~mm}^{3}, 5.49 \mathrm{~mm}^{2}, 0.53$, $26.82 \mathrm{~g}, 1.27 \mathrm{~g} / \mathrm{cm}^{3}, 0.603 \mathrm{~g} / \mathrm{cm}^{3}, 52.52 \%$, and $11.60 \%$ respectively.

2. Some mechanical properties as angle of repose and friction angle were studied.

-The highest value in dynamic angle of repose $30.0^{\circ}$ with plastic while the lowest value in dynamic angle of repose $26.3^{\circ}$ for plywood.

-The lowest values of static coefficient of friction was 0.46 with plywood while the highest value was 0.65 with glass.

3. Some aerodynamic properties of quinoa seeds as terminal velocity and Reynolds number were studied. The seeds gave values of $0.79 \mathrm{~m} / \mathrm{s}$ and 88.25for average terminal velocity and average Reynolds number respectively, so, the flow was laminar.

\section{REFERENCES}

ASAE Standards (1999). Standard Engineering Practices Data (46th Edn). American Society of Agricultural Engineers, St Joseph, MI, USA 
Awady M. N. and A. S. El-Sayed (1994). Separation of peanut seeds by air stream. (Egypt); Misr J. Ag. Eng., 11(1): 137-147.

Brenes E, F. Crespo and K. Madrigal (2001). El cluster de quinoa en Bolivia: Diagn!ostico competitivo y recomendaciones estrat!egicas. (The quinoa cluster: competitive diagnosis and strategic recommendations). Documento Proyecto Andino de Competitividad, 54pp. Instituto Centroamericano de Administraci!on de Empresas INCAE

FAO (2011). Quinoa: An ancient crop to contribute to world food security. Technical report of the 37 th FAO Conference. Rome, Italy.

Gallagher, E., Gormley, T. R., and Arendt, E. K. (2004). Recent advances in the formulation of gluten-free cereal-based products. Trends in Food Science \& Technology, 15(3-4), 143-152

Kachru, R. P., Gupta, R. K., and Alam, A. (1994). Physico-chemical constituents and engineering properties of food crops. Scientific Publishers ISBN: 81-7233-083-9

Mansouri, A., Mirzabe, A. H., \& Ráufi, A. (2017). Physical properties and mathematical modeling of melon (Cucumis melo L.) seeds and kernels. Journal of the Saudi Society of Agricultural Sciences, 16(3), 218-226

Mohsenin N. N. (1986). Physical properties of plant and animal materials. Gordon and Breach Sc. Publ., N.Y.

Siqueira V. C., O. Resende and T. H. Chaves (2013). Shape and size of Jatropha beans (Jatropha curcas L.) during drying at different temperatures. (Brazil); Rev. Ceres Viçosa; 60 (6): 820 - 825.

USDA, (2015). United States Department of Agriculture. National Nutrient Databasefor Standard Reference Release, 28 (Basic Reports). 
Vilche, C., M. Gely,., and E. Santalla, (2003). Physical properties of quinoa seeds. Biosystems Engineering, 86(1), 59-65.

\section{الملخص العربى}

\section{بعض الخصائص الطبيعية والميكاتيكية والإيروديناميكية لبذور نبات الكينوا}

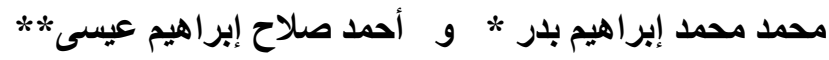

تعد بذور الكينوا من البذور الهامة التي تستخدم في التغذية وخصوصا لدى الأشخاص الذين

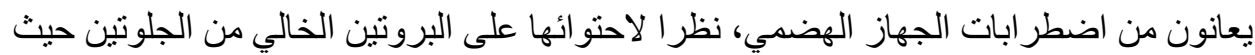

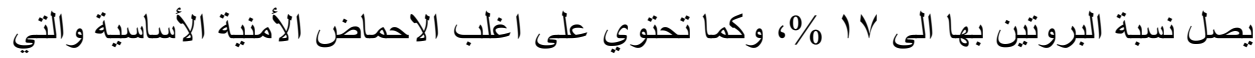

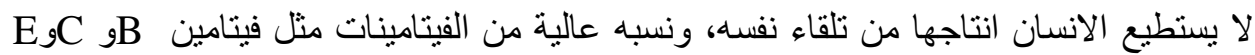

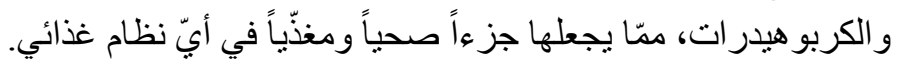

ولذا نهدف هذه الدراسة إلى نوفير قاعدة معلومات لبعض الخصائص الطبيعية والميكانيكية والإيروديناميكية لبذور نبات الكينوا لما تمثله هذه الخصائص من أهمية في عمليات التداول

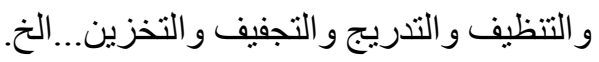
وقد تم تلخيص نتائج هذه الاراسة كالاتي:

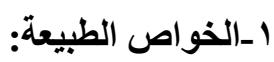
تم دراسة بعض الخو اص الطبيعية للبذور مثل الطول و العرض و السمك و القطر الهندسي و القطر

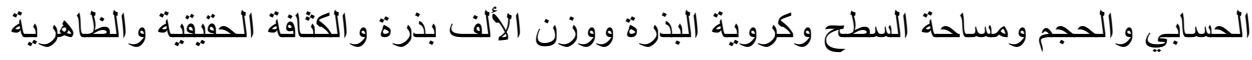
و المسامية و المحتوى الطوبى على أساس جاف.

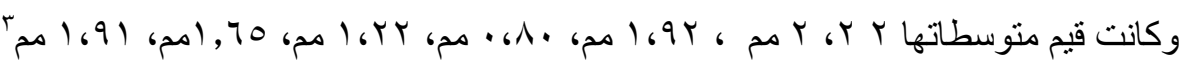

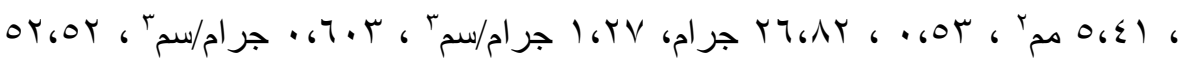

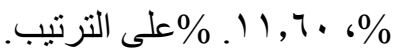

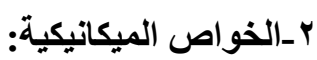

- - م دراسة بعض الخواص الميكانيكية كزاوية المكوث ومعامل الاحتكاك مع أسطح

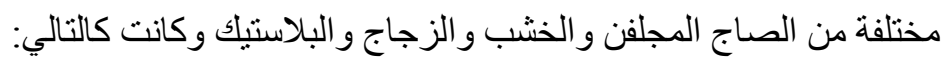

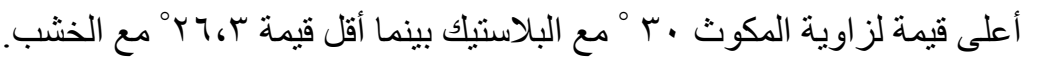
أعلى قيمة لمعامل الاحتكاك 70 ، ، مع الزجاج بينما كانت أقل قيمة 7؟؛، ، مع الخشب.

*أستاذ مساعد بقسم هندسة تصنيع المنتجات الزراعية ـ كلية الهندسة الزراعية - جامعة الأزهر بالقاهرة. *مدرس بقسم هندسة تصنيع المنتجات الزراعية ـ كلية الهندسة الزراعية - جامعة الأزهر بالقاهرة. 


\section{r-الخواص الإيروديناميكية:}

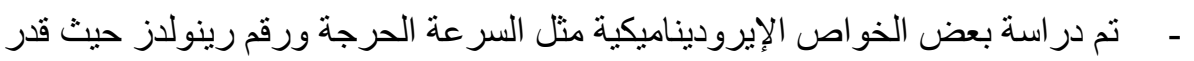

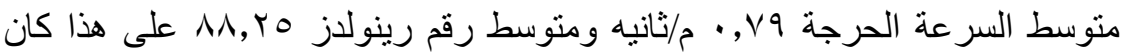

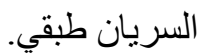

